Check for updates

London, UK

Cite this as: BMJ 2020;370:m3729 http://dx.doi.org/10.1136/bmj.m3729 Published: 28 September 2020

\section{Fostering inclusivity: the consultant obstetrician and gynaecologist}

\author{
The consultant obstetrician and gynaecologist tells Marika Davies about the joy of working with \\ younger doctors and the magic of his specialty
}

\section{Marika Davies}

When Steve Smith is teaching registrars how to operate, he tries not to criticise what they do. "I try to be completely positive," he says. "If they're doing something in a way that wouldn't be my first choice but they're obviously doing it well and know what they're doing, I wouldn't dream of interfering and saying you must do it my way."

Smith aims to give trainees the experience to consolidate the skills they already have while providing them with the opportunity to try new skills. "So that they can progress rather than be taken back and told to do it a different way each time," he explains.

Smith decided he wanted to study medicine when he was a teenager. "I saw a television programme about an obstetrician delivering twins and thought it was the most awesome thing I'd ever seen," he recalls.

While at medical school his placement in obstetrics and gynaecology was the most enjoyable part of his undergraduate time. "I was privileged to have a lot of good teachers," he says. "They were all fantastic."

One of these teachers, consultant obstetrician Bob Atlay, had a lasting influence on the way Smith works with junior colleagues. "He treated students with respect and was very inclusive of his juniors," recalls Smith. "Even as a student you felt part of the action rather than just someone who was hanging around getting in the way."

After graduating from the University of Liverpool medical school in 1988, Smith started his obstetrics and gynaecology training straight after house jobs and has been a consultant obstetrician and gynaecologist for the past 20 years.

He says it is a privilege to deliver a baby and to be involved in such an important part of someone's life. "There's something I find quite magical about it and it still fascinates me to this day," he says.

Smith also enjoys working with young people. "I'm always aware of the fact that you're dealing with equals or betters who are just at a different stage in the life cycle from you," he says. "I find it very stimulating."

His advice to junior doctors is to be honest and to ask for help when they need it. "Whenever you're given a set of instructions, make sure that you know exactly what's been asked of you," he says. "And be honest if you don't have the skills to complete the task."

When bullying was highlighted as a problem within the specialty, Smith was appointed as the workplace behaviour champion for the East Midlands region by the Royal College of Obstetricians and Gynaecologists.
"I've spent a lot of time with juniors and the seniors they feel have been bullying them, trying to resolve those problems," he says. "It's difficult, because inevitably there's going to be somebody disappointed. It isn't easy at all."

Away from work, Smith does a lot of walking, is an avid reader, collects stamps, and is fascinated by ink pens. He tries to swim every day. "It keeps me sane," he says. "Even if I'm worried about something, while I'm swimming I have the ability to forget about it."

During the covid-19 crisis, Smith has been keen to ensure that colleagues isolating at home are supported and feel a part of the department. He has also noticed a change for the better in the provision of medical terminations of pregnancy, because of a temporary change in the law allowing patients to take the necessary drugs at home instead of on licensed premises.

"The women think it's a great system. One of the good things that could come out of the pandemic is if the government makes the provision of home terminations available permanently," says Smith. "Although we're dealing with a horrible situation at the moment, there could be some beneficial knock-ons. We can only hope so."

\section{Nominated by Rani Prajwala}

Mr Smith is the most down to earth and kind obstetrician and gynaecologist I have ever come across. He does his work with passion and always goes that extra mile to help patients, colleagues, and trainees. He ensures that trainees have a safe and positive environment to work in.

Working in an intense acute specialty like obstetrics and gynaecology, where trainee attrition rate, stress, and burnout are overwhelming, he is a breath of fresh air. As a mentor he is approachable and his empathy, compassion, and advice have helped many trainees through a professional crisis.

He was the anti-bullying champion for East Midlands deanery school of obstetrics and gynaecology and rightly so. It has been a privilege to have been his trainee.

Rani Prajwala is a locum consultant in obstetrics and gynaecology at Rotherham General Hospital.

Nominate a role model: to nominate someone who has been a role model during your medical career, send their name, job title, and the reason for your nomination to arimmer@bmj.com. 